\title{
Spatial distribution of adult Anthonomus grandis Boheman (Coleoptera: Curculionidae) and buds with feeding punctures on conventional and Bt cotton
}

\section{Distribuição espacial de adultos e botões com orifício de alimentação de Anthonomus grandis Boheman (Coleoptera: Curculionidae) em algodoeiro convencional e Bt}

\author{
Paulo Rogério Beltramin da Fonseca ${ }^{1 *}$; Marcos Gino Fernandes ${ }^{2}$; \\ Paulo Eduardo Degrande 3 ; Thiago Alexandre Mota ${ }^{4}$; Samir Oliveira Kassab ${ }^{4}$
}

\begin{abstract}
Dispersion patterns of Anthonomus grandis adults and damaged squares with their feeding punctures are important to enhance pest monitoring and control on cotton. In this research we performed probabilistic analyses of the distribution patterns of adults and squares with feeding punctures of $A$. grandis on two cotton genotypes, Bt and non-Bt near isogenic lines. We conducted the field experiment in two experimental areas; each area had 100 plots composed of seven rows, each seven metros long. Between Jan and May 2010, 16 samplings were made, in each, five plants were evaluated per plot by counting the adults and damaged squares. The dispersion indexes (ratio of the variance/mean, the Morisita index, and Exponent $\mathrm{k}$ of the Binomial Negative Distribution) and the theoretical distribution of frequencies (Poisson, Negative Binomial and Positive Binomial) were calculated. No differences between cotton genotypes were found. The spatial distribution of $A$. grandis adults fit the Negative Binominal (aggregate) and Positive Binominal (uniform) distributions, depending on the number of days after cotton emergence. The dispersion analyses of the feeding damaged squares on the $\mathrm{Bt}$ and conventional cotton revealed Poisson (random), Negative Binominal (aggregate) and Positive Binominal (uniform) distribution patterns in sequence during the crop cycle.
\end{abstract}

Key words: Boll weevil, damage, pest movement, horizontal dispersion

\section{Resumo}

O conhecimento dos arranjos de dispersão para adultos e botões com orifício de alimentação de Anthonomus grandis em cultivares de algodoeiro é necessário para aperfeiçoar o monitoramento e controle da praga. Esta pesquisa teve por objetivo realizar análises probabilísticas dos padrões de distribuição espacial dos adultos e botões com orifícios de alimentação de $A$. grandis em duas cultivares de algodão Bt e não Bt. O estudo foi conduzido a campo em duas áreas experimentais, cada uma composta por 100 parcelas de sete linhas de sete metros de comprimento. Em 16 amostragens avaliaram-se cinco

\footnotetext{
${ }^{1}$ Eng $^{0}$ Agr $^{\circ}$, Discente de Doutorado em Agronomia (Produção Vegetal), Faculdade de Ciências Agrárias, FCA, Universidade Federal da Grande Dourados, UFGD. Rod. Dourados-Itahum, Km 12, CP 533, Aeroporto, CEP: 79804-970, Dourados, MS. E-mail: prbeltramin@hotmail.com

${ }^{2}$ Prof. Adjunto, Faculdade Ciências Biológicas e Ambientais, FCBA/UFGD, Dourados, MS. E-mail: marcosfernandes@ufgd.edu. br

${ }^{3}$ Prof. Associado, Faculdade de Ciências Agrárias, FCA/UFGD, Dourados, MS. E-mail: paulodegrande@ufgd.edu.br

${ }^{4}$ Biólogos, Discente(s) de Doutorado(s) em Entomologia e Conservação da Biodiversidade, Faculdade de Ciências Biológicas e Ambientais, FCBA/UFGD, Dourados, MS. E-mail: thiamota@hotmail.com; samirkassab@gmail.com

${ }^{*}$ Author for correspondence
} 
plantas por parcela através da contagem dos adultos e dos botões com orifício de alimentaçãoentre janeiro e maio de 2010. Foram calculados os índices de dispersão (razão variância/média, índice de Morisita e Expoente k da Distribuição Binomial Negativa) e as distribuições teóricas de freqüência (Poisson, Binomial Negativa e Binomial Positiva). Não houve diferença estatística entre as cultivares avaliadas. A distribuição espacial dos adultos de A. grandis, nas cultivares Bt e não Bt, ajustou-se nos arranjos probabilísticos de distribuição binomial negativa (agregado) e distribuição binomial positiva (uniforme), conforme os dias após a emergência do algodoeiro. As análises de dispersão para os botões com orifícios de alimentação nas culturas Bt e convencional mostraram os modelos espaciais de Poisson (aleatório), distribuição binomial negativa (agregado) e distribuição binomial positiva (uniforme), em seqüência, durante o ciclo da cultura.

Palavras-chave: Bicudo-do-algodoeiro, danos, movimento da praga, dispersão horizontal

\section{Introduction}

The cotton boll weevil, Anthonomus grandis (Boheman) (Coleoptera: Curculionidae) has great economic importance for the cotton industry in South America. Products such as fibers, threads, cloth and clothing obtained from the cotton have been sought after in the domestic as well as the external market, especially in European countries (ALCANTRA et al., 2011). This weevil has a high reproductive rate and is a very destructive pest (FONSECA et al., 2011; CHOI et al., 2011). Adults of $A$. grandis use their mouthparts to pierce the flower buds of cotton Gossypium hirsutum (Linnaeus, 1753), making punctures where they feed and oviposit (BUSOLI et al., 2004; SILVA; BEZERRA; SILVA, 2008); these punctures are here in called feeding punctures and oviposition punctures. Control of this pest is usually done with chemicals that are not always effective. Furthermore, they also kill the natural enemies of the boll weevil (BASTOS et al., 2005; NEVES et al., 2010).

In order to reduce the number of pesticide applications for some target pests, a new method of insect control, involving the use of transgenic plants, has been developed (LIU et al., 2005). Genetically modified cotton is the result of recombinant DNA technology, through which some genes from the bacterium Bacillus thuringiensis Berliner (Bt) were transferred into the genome of the plant. These genes are responsible for encoding the Cry1Ac protein, for example, which is toxic to the larvae of some pest Lepidoptera (SHARMA; ORTIZ, 2000).
Measures aimed to control the cotton boll weevil should take population densities, monitored through regular sampling, into account. The first step in establishing the criteria to survey a population and prepare a sampling plan is to know the spatial distribution of the species of interest (BARBOSA, 2003). Thus, a fast and efficient sampling plan, especially in large agricultural areas, is essential in order to establish an efficient IPM strategy (FERNANDES; BUSOLI; BARBOSA, 2003).

The spatial distributions of crop pests can be aggregated, uniform or random. These distributions are called negative binomial, positive binomial and Poisson, respectively (BARBOSA; PERECIN, 1982). This classification is based on the relationship between the mean and the variance of the data (ELLIOT, 1979). However, despite the benefits of Bt crops, it is not known exactly how they affect insect populations in the crop (RODRIGUES; FERNANDES; SANTOS, 2010).

Understanding the distribution behavior of non-target pests on transgenic plants is necessary 1) to determine their spatial distribution and 2) to determine whether or not to make changes in the sampling strategy (for instance, to make alterations in the size of the sample or sampling units).

This study aimed to analyze the pattern of spatial distribution, and to compare the [distribution] behavior of $A$. grandis adults and their feeding punctures on $\mathrm{Bt}\left(\mathrm{NuOpal}^{\circledR}\right)$ and non-Bt cotton $\left(\right.$ DeltaOpal $\left.^{\circledR}\right)$. 


\section{Material and Methods}

We conducted the field experiment during the 2009/2010 agricultural season at the municipality of Dourados, Mato Grosso do Sul (latitude $22^{\circ} 11^{\prime}$ $55^{\prime \prime} \mathrm{S}$, longitude $54^{\circ} 56^{\prime} 23^{\prime \prime} \mathrm{W}$ and 454 masl), at the Experiment Station of the Agricultural Science Faculty, Federal University of Grande Dourados, (UFGD). We planted the seeds on 30 Dec 2009 at 14 seeds per meter and $0.9 \mathrm{~m}$ between rows. The basic fertilization was $450 \mathrm{~kg} \mathrm{ha}^{-1}$ of N-P $\mathrm{P}_{5}-\mathrm{K}_{2} \mathrm{O}$, $08-20-20+0.3 \% \mathrm{Zn}$, and $35 \mathrm{DAE}$ (days after plant emergence) we applied $150 \mathrm{~kg} \mathrm{ha}^{-1}$ of urea $(45 \% \mathrm{~N})$.

On 03 Jan 2010 the plants started to emerge with an average density of about 12.8 plants per $\mathrm{m}$. On 18 Jan 2010 we sprayed them with the herbicides Staple ${ }^{\circledR}$ (pirithiobaque-sodium), Envoke ${ }^{\circledR}$ (trifloxissulfuronsodium) and EW Fusilade ${ }^{\circledR}$ (fluazifop-p-butyl 37), to control the weeds.

We evaluated the spatial distribution of adults and feeding punctures of $A$. grandis in 2 areas (treatments), one with the $\mathrm{Bt}\left(\mathrm{NuOpal}^{\circledR}\right)$ and another with the non-Bt cotton $\left(\right.$ DeltaOpal $\left.{ }^{\circledR}\right)$. Each area had 100 plots each composed of 7 rows $\times 7 \mathrm{~m}$ in length, and area of $44.10 \mathrm{~m}^{2}$. The sampling methodology used for the vegetative stage was the whole-plant method, and during the reproductive phase, the preferred bud was sampled (DEGRANDE, 1998).

Samples were taken at random on a weekly basis, from 5 plants in the 5 central rows of each plot, totaling 500 plants per treatment. During sampling we counted the adults and the buds with feeding punctures of $A$. grandis. The total evaluation period lasted from 9 Jan 2010 to 1 May 2010, totaling 16 samplings in each cultivar. No insecticide was applied in the experimental area.

For data analysis, we obtained the mean and variance of the number of adults and flower buds (squares) with feeding punctures of $A$. grandis per plot at each sampling date, and used the relationship between these values as indicative of a spatial distribution (ELLIOT, 1979). The dispersion indexes, described as follow, were calculated using the Excel ${ }^{\circledR}$ program.
Variance/mean ratio (VMR) is the ratio of the variance to the mean $\left(I=\mathrm{s}^{2} / m\right)$. It is used to measure the deviation from the random expectation. When the $V M R=1$, the spatial distribution is random; a $V M R<1$ is compatible with uniform distribution; and $V M R<1$ indicatesthat the distribution is aggregated (RABINOVICH, 1980). The departure from randomness can be tested using the chisquare with $n$-1 degrees of freedom, $\chi^{2}=(n-1) \mathrm{s}^{2} / m$ (ELLIOT, 1979).

Morisita index $\left(I_{\delta}\right)$ is relatively independent from the mean and from the number of samples. When $I_{\delta}=1$, the distribution is random, when $I_{\delta}>1$, the distribution is contagious and when $I_{\delta}<1$, the distribution is regular (MORISITA, 1962).

Exponent $k$ of the Negative Binomial Distribution is a suitable index of dispersion only when the size and numbers of sample units are the same in each sample, and it is influenced by the size of the sample units. This parameter is an inverse measure of the degree of aggregation, in which case negative values indicate a regular or uniform distribution, positive values near zero, an aggregate distribution, and values greater than eight indicate a tendency towards randomness (PIELOU, 1977; SOUTHWOOD, 1978; ELLIOT, 1979). According to Poole's interpretation (1974), however, $0<\mathrm{k}<8$ indicates an aggregated distribution, and $0>\mathrm{k}>8$ points to random distribution. Theoretical distribution of frequencies: the theoretical distributions of frequencies used to evaluate the spatial distribution of the populations are presented below, according to Young e Young (1998).

Poisson distribution, also known as random distribution, is characterized by a variance value equal to the mean $\left(\mathrm{s}^{2}=m\right)$. Positive Binomial Distribution: describes a uniform distribution with variance lower than the mean $\left(\mathrm{s}^{2}<m\right)$.

When in the Negative Binomial Distribution the variance is greater than the mean, it thereby indicates an aggregated distribution, and has 2 parameters: the mean $(m)$ and the parameter $k(k>0)$. 
The Adherence Chi square test isused to verify how the data collected in the field fit thetheoretical distribution frequencies.

The test compares the total observed frequencies with the expected frequencies in the sampled area, according to Young e Young (1998); these frequencies are defined by the product of the probabilities of each class and the total number of sample units used. For this test we chose to establish a minimal expected frequency equal to one. Statistical analysis was performed using the chi-square at $5 \%$ probability.

\section{Results and Discussion}

The on set of the appearance of flower buds on the $\mathrm{Bt}$ cotton coincided with that on non-Bt cotton plants (Figure 1a). However, the presence of $A$. grandis adults on the plants was first detected 21 days after plant emergence (DAE), i.e., before the flowering period. These results do not corroborate those of Busoli et al. (1994), who reported that the pest appears in cotton fields only after the reproductive plant structures have appeared.

Figure 1. Percentage of the numbers for adult Anthonomus grandis (a) and number of feeding punctures on cotton buds ("squares") per 5 plants (b) on cotton NuOpal ${ }^{\circledR}$ and DeltaOpal ${ }^{\circledR}$ between 7 and 112 DAE in 2009/2010.
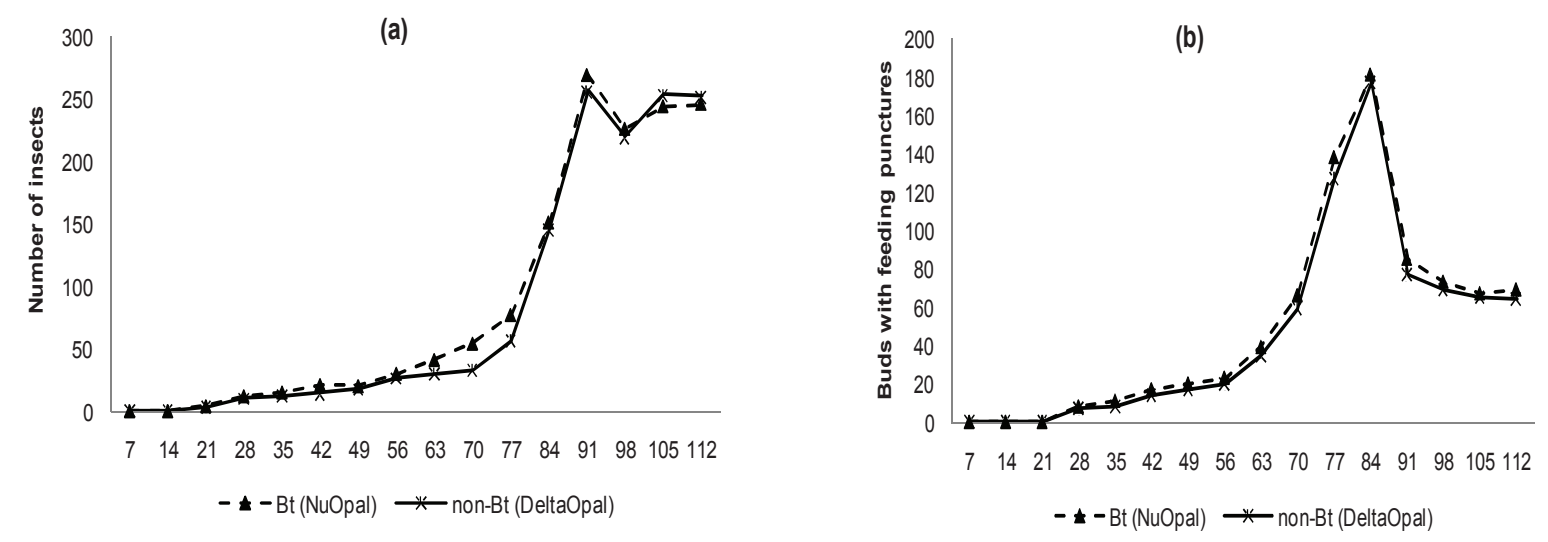

Source: Elaboration of the authors.

In 16 samples (a total of 2,735 insects) we found $51.55 \%$ on the Bt cultivar and $48.44 \%$ on conventional cotton. The peak of adult population happened at $91 \mathrm{DAE}$ (Apr) on both $\mathrm{NuOpal}^{\circledR}$ and DeltaOpal $^{\circledR}$ cultivars with 2.69 and 2.56 adults on five plants/plot, respectively (Figure 1a). In this sense, studies by Thomazoni et al. (2010) also showed that $\mathrm{NuOpal}^{\circledR} \mathrm{Bt}$ cotton had greater percentage of $A$. grandis adults than the DeltaOpal ${ }^{\circledR}$ non-Bt cultivar.

The higher $A$. grandis population found on $\mathrm{Bt}$ crop maybe a result of the lack of inter-specific competition, which is more intense between populations ofarthropods breeding on conventional crops, such as those of the target lepidopteran Alabama argillacea (Hübner, 1818), Heliothis virescens (Fabricius, 1781) and Pectinophora gossypiella (Saunders, 1844) (CATTANEO et al., 2006; ROMEIS et al., 2006). However, this hypothesis needs to be tested more rigorously.

Floral buds ("squares") with feeding punctures on $\mathrm{Bt}$ and conventional cultivars were observed beginning with the fourth sampling, at $28 \mathrm{DAE}$, during the evaluation period (Figure 1b). The greatest number of buds with feeding punctures was found on the Bt crop, which represented $51.91 \%$ of 
the total buds sampled. A total of 1,539 buds with $A$. grandis feeding punctures was counted from the first to the last evaluation, with 799 on Bt cotton and 740 on non-Bt cotton (Figure 1b).

The largest number of buds with feeding punctures was found during the first 12 assessments (84 DAE) on Bt and non-Bt crops, with an average of 1.81 and 1.77 per 5 plants, respectively (Figure $1 b)$. The results of this study are similar to those reported by Busoli et al. (2004), who observed that individuals of $A$. grandis prefer feeding on the flower buds located on the upper third of the plant.

On the other hand, adult weevils showed no preferences towards buds of either cultivar. According to Tomquelski (2009), the number of reproductive structures on $\mathrm{Bt}$ and non-Bt cotton which are attacked does not differ significantly. Study of Busoli (1991) reports that the damage caused by $A$. grandis feeding punctures were more severe than the chemical control level $(10 \%)$ of flower buds attacked, for the conditions in Brazil.

\section{Aggregation indexes for a. grandis adults}

The variance/mean ratio (I) calculated for adults of $A$. grandis on $\mathrm{Bt}\left(\mathrm{NuOpal}^{\circledR}\right)$ cotton was statistically equal to 1 , ranging from 0.918 to 1.352 , in 12 samplings, indicating randomness (Table 1). By contrast, the same index calculated for adults in the non-Bt (DeltaOpal ${ }^{\circledR}$ ) treatment was statistically equal to 1 (random) in 9 samplings, and greater than 1in 5 samplings, the latter indicating an aggregate distribution (Table 1).

According to the results of the Morisita index $\left(I_{\delta}\right)$ for the Bt treatment in 12 samplings of $A$. grandis adults, a total of 16 values were equal to $1(0.000$ to 2.727 ), and only the $12^{\text {th }}$ sampling ( 84 DAE) had a value above 1 (1.419) (Table 1).

The Morisita test index $\left(I_{\delta}\right)$ applied to the conventional crop revealed that 8 out of 16 samplings had values equal to 1 ( 0.846 to 1.578$)$ and 5 had values greater than 1 with different statistical values
(01). Most evaluations resulted in values equal to 1 , i.e., indicating randomness (Table 1).

Analysis of the exponent $k \square$ for $\mathrm{Bt}\left(\mathrm{NuOpal}^{\circledR}\right)$ showed that, out of 16 field samplings of adults of $A$. grandis, 6 had an aggregate distribution (values from 0.624 to 4.181 ), 5 had a random distribution, and 3 had a uniform distribution, with values of -1.960 , -1.225 and 3.717, respectively (Table 1 ). When data obtained from the non-Bt cotton $\left(\right.$ DeltaOpal ${ }^{\circledR}$ ) was analyzed, out of 16 samplings, 9 had an aggregate distribution (Table 1), 3 had a random distribution and 2 had a uniform distribution.

Aggregation indexes for buds with feeding punctures

The variance/mean ratio (I) calculated for feeding punctures on the $\mathrm{Bt}\left(\mathrm{NuOpal}^{\circledR}\right)$ cultivar resulted in 9 samplings with values ranging from 0.918 to 1.394 and thus statistically equal to 1 , indicating randomness, (Table 1). For the non-Bt $\left(\right.$ DeltaOpa $l^{\circledR}$ ) cotton, index I had 10 samples with values statistically equal to 1 (random), and 2 values greater than 1 and (01) smaller than 1 (Table 1).

In summary, the Morisita index $\left(I_{\delta}\right)$ applied to the number of buds with feeding punctures in the Bt treatment revealed that 5 samplings out of 16 , had values equal to 1 (0.907 to 1.176$)$ (Table 1$)$.

When applied to the buds with feeding punctures on the conventional cotton, the Morisita index $\left(I_{\delta}\right)$ indicated that, out of 16 samplings, 10 had values greater than the unit, with statistical values differing from (01) (Table 1).

The exponent $k$ for the buds with feeding punctures on the $\mathrm{Bt}\left(\mathrm{NuOpal}^{\circledR}\right)$ cotton indicated that out of 16 samples, 8 had an aggregate distribution (values from 0.182 to 7.411 ), and 5 had a uniform distribution (values $-1.225,-3.308,-10.908$, -19.058 and -36.750 ) (Table 1). In the non-Bt $\left(\right.$ DeltaOpal $\left.{ }^{\circledR}\right)$ treatment, out of 16 field samplings (Table 1), the exponent $k$ indicated an aggregate distribution for 9 , a random distribution for 2 , and a uniform distribution for 2 . 


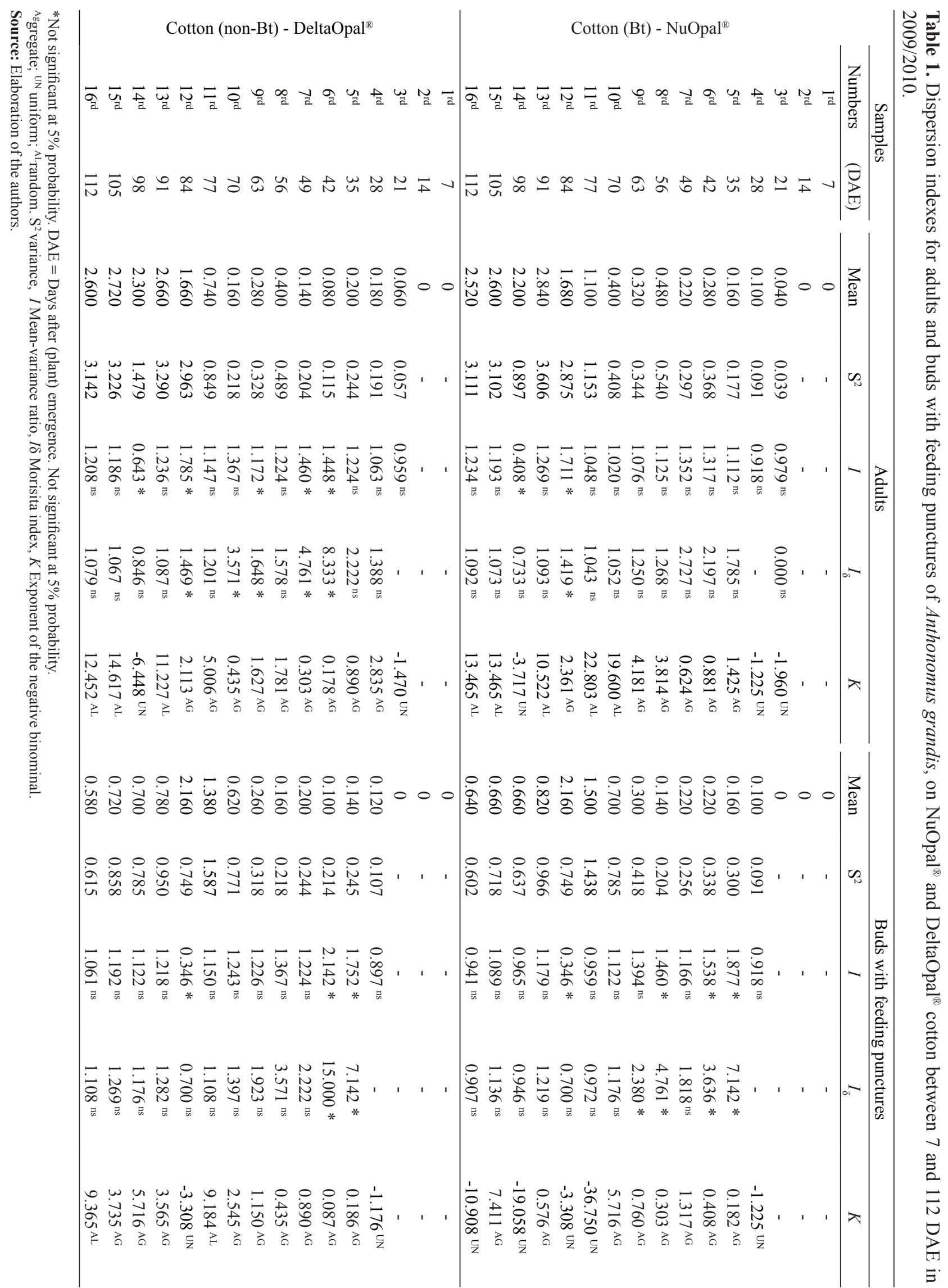


Table 2. Chi-square test of the fit of the expected frequencies to the poisson, negative binomial $(\mathrm{Bn})$ and positive binomial (Bp) distributions, spatial arrangement for adults and buds with feeding punctures of Anthonomus grandis, on cotton NuOpal ${ }^{\circledR}$ and DeltaOpal ${ }^{\circledR}$ between 7 and 112 DAE in 2009/2010.

\begin{tabular}{|c|c|c|c|c|c|c|c|c|c|c|}
\hline & \multicolumn{2}{|c|}{ Samples } & \multicolumn{3}{|c|}{ Adults } & \multirow{2}{*}{ 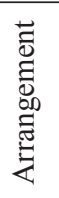 } & \multicolumn{3}{|c|}{ Buds with feeding punctures } & \multirow{2}{*}{ 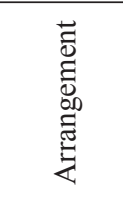 } \\
\hline & Numbers & (DAE) & Poisson & $\mathrm{Bn}$ & $\mathrm{Bp}$ & & Poisson & $\mathrm{Bn}$ & $\mathrm{Bp}$ & \\
\hline \multirow{16}{*}{ 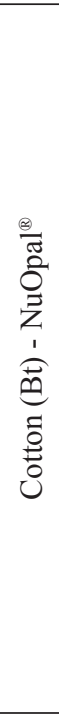 } & $1^{\text {rd }}$ & 7 & $\mathrm{i}$ & $\mathrm{i}$ & $\mathrm{i}$ & \multirow{9}{*}{ 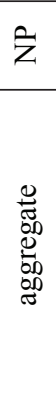 } & $\mathrm{i}$ & $\mathrm{i}$ & $\mathrm{i}$ & \multirow{3}{*}{ z } \\
\hline & $2^{\text {rd }}$ & 14 & $\mathrm{i}$ & $\mathrm{i}$ & $\mathrm{i}$ & & $\mathrm{i}$ & $\mathrm{i}$ & $\mathrm{i}$ & \\
\hline & $3^{\text {rd }}$ & 21 & $0.042 *$ & $0.083^{\mathrm{NS}}$ & $0.037 *$ & & i & i & i & \\
\hline & $4^{\mathrm{rd}}$ & 28 & $0.285^{*}$ & $0.576^{\mathrm{NS}}$ & $0.255^{*}$ & & $0.285^{*}$ & $0.576^{\mathrm{NS}}$ & $0.255^{\mathrm{NS}}$ & random \\
\hline & $5^{\text {rd }}$ & 35 & $0.510^{*}$ & $0.169^{\mathrm{NS}}$ & $0.630^{\mathrm{NS}}$ & & $35.061^{*}$ & $9.110^{*}$ & $45.133^{*}$ & \multirow{5}{*}{ 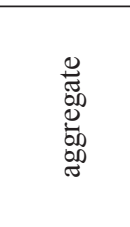 } \\
\hline & $6^{\mathrm{rd}}$ & 42 & $5.812 *$ & $1.451^{\mathrm{NS}}$ & $7.395 *$ & & $13.112^{*}$ & $3.037^{\mathrm{NS}}$ & $16.743^{*}$ & \\
\hline & $7^{\text {rd }}$ & 49 & $6.061^{*}$ & $3.276^{\mathrm{NS}}$ & $6.720^{*}$ & & $1.563^{*}$ & $0.661^{\mathrm{NS}}$ & $1.826^{\mathrm{NS}}$ & \\
\hline & $8^{\text {rd }}$ & 56 & $0.719^{*}$ & $0.962^{\mathrm{NS}}$ & $0.975^{\mathrm{NS}}$ & & $7.455^{*}$ & $4.020^{\mathrm{NS}}$ & $8.245^{*}$ & \\
\hline & $9^{\text {rd }}$ & 63 & $5.284 *$ & $4.352^{\mathrm{NS}}$ & $6.060^{*}$ & & $10.443^{*}$ & $6.743^{\mathrm{NS}}$ & $11.338^{*}$ & \\
\hline & $10^{\text {rd }}$ & 70 & $1.199^{*}$ & $1.843^{\mathrm{NS}}$ & $1.333^{\mathrm{NS}}$ & \multirow{7}{*}{$\begin{array}{l}\text { 总 } \\
\stackrel{0}{\Xi}\end{array}$} & $2.103^{*}$ & $4.273^{\mathrm{NS}}$ & $0.490^{\mathrm{NS}}$ & \multirow{5}{*}{ 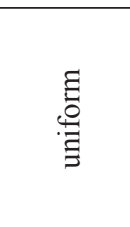 } \\
\hline & $11^{\mathrm{rd}}$ & 77 & $2.815^{*}$ & $9.091 *$ & $3.347^{\mathrm{NS}}$ & & $1.404^{*}$ & $15.514^{*}$ & $1.231^{\mathrm{NS}}$ & \\
\hline & $12^{\mathrm{rd}}$ & 84 & $6.801^{\mathrm{NS}}$ & $2.261^{\mathrm{NS}}$ & $8.188^{*}$ & & $22.185^{*}$ & $76.492 *$ & $5.106^{*}$ & \\
\hline & $13^{\text {rd }}$ & 91 & $3.557^{\mathrm{NS}}$ & $22.226^{*}$ & $4.641 *$ & & $3.401^{*}$ & $4.151^{\mathrm{NS}}$ & $3.162^{\mathrm{NS}}$ & \\
\hline & $14^{\text {rd }}$ & 98 & 11.899* & $57.367^{*}$ & $6.271^{*}$ & & $5.884^{*}$ & $8.940 *$ & $5.945^{*}$ & \\
\hline & $15^{\mathrm{rd}}$ & 105 & $4.237^{\mathrm{NS}}$ & $33.775^{*}$ & $2.236^{\mathrm{NS}}$ & & $3.978^{*}$ & $5.331^{\mathrm{NS}}$ & $4.198 *$ & \\
\hline & $16^{\mathrm{rd}}$ & 112 & $5.306^{\mathrm{NS}}$ & $32.131 *$ & $3.830^{\mathrm{NS}}$ & & $4.268^{*}$ & $7.457^{\mathrm{NS}}$ & $4.275^{*}$ & regate \\
\hline \multirow{16}{*}{ 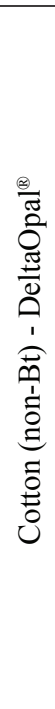 } & $1^{\mathrm{rd}}$ & 7 & i & $\mathrm{i}$ & $\mathrm{i}$ & \multirow{2}{*}{$\hat{z}$} & $\mathrm{i}$ & $\mathrm{i}$ & $\mathrm{i}$ & \multirow{3}{*}{ 艺 } \\
\hline & $2^{\text {rd }}$ & 14 & i & $\mathrm{i}$ & $\mathrm{i}$ & & $\mathrm{i}$ & $\mathrm{i}$ & $\mathrm{i}$ & \\
\hline & $3^{\text {rd }}$ & 21 & $5.713 *$ & $2.925^{\mathrm{NS}}$ & $6.355^{*}$ & \multirow{10}{*}{ 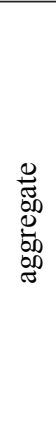 } & $\mathrm{i}$ & $\mathrm{i}$ & $\mathrm{i}$ & \\
\hline & $4^{\mathrm{rd}}$ & 28 & $0.234^{*}$ & $0.204^{\mathrm{NS}}$ & $0.304^{\mathrm{NS}}$ & & $0.421^{*}$ & $0.857^{\mathrm{NS}}$ & $0.377^{\mathrm{NS}}$ & random \\
\hline & $5^{\text {rd }}$ & 35 & $2.373^{*}$ & $1.015^{\mathrm{NS}}$ & $2.720^{\mathrm{NS}}$ & & $49.518^{*}$ & $12.208^{*}$ & 64.613* & \multirow{5}{*}{ 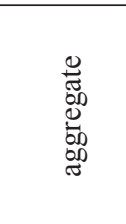 } \\
\hline & $6^{\mathrm{rd}}$ & 42 & $5.713^{*}$ & $2.925^{\mathrm{NS}}$ & $6.355^{*}$ & & $5.713^{*}$ & $2.925^{\mathrm{NS}}$ & $6.355^{*}$ & \\
\hline & $7^{\text {rd }}$ & 49 & $7.455^{*}$ & $4.020^{\mathrm{NS}}$ & $8.245^{*}$ & & $2.373^{*}$ & $1.015^{\mathrm{NS}}$ & $2.720^{\mathrm{NS}}$ & \\
\hline & $8^{\text {rd }}$ & 56 & $1.729^{*}$ & $0.401^{\mathrm{NS}}$ & $2.271^{\mathrm{NS}}$ & & $5.119^{*}$ & $2.579^{\mathrm{NS}}$ & $5.710^{*}$ & \\
\hline & $9^{\text {rd }}$ & 63 & $6.880^{*}$ & $3.554^{\mathrm{NS}}$ & $8.327 *$ & & $3.296^{*}$ & $1.670^{\mathrm{NS}}$ & $3.727^{\mathrm{NS}}$ & \\
\hline & $10^{\mathrm{rd}}$ & 70 & $5.119^{*}$ & $2.579^{\mathrm{NS}}$ & $5.710^{*}$ & & $3.836^{*}$ & $2.467^{\mathrm{NS}}$ & $1.407^{\mathrm{NS}}$ & \multirow{3}{*}{ 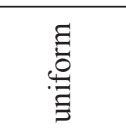 } \\
\hline & $11^{\mathrm{rd}}$ & 77 & $2.527 *$ & $2.801^{\mathrm{NS}}$ & $2.596^{\mathrm{NS}}$ & & $0.592^{\mathrm{NS}}$ & $10.544 *$ & $0.349^{\mathrm{NS}}$ & \\
\hline & $12^{\mathrm{rd}}$ & 84 & $8.428^{\mathrm{NS}}$ & $1.029^{\mathrm{NS}}$ & $11.081^{*}$ & & $22.898^{*}$ & $77.741 *$ & $5.671^{*}$ & \\
\hline & $13^{\text {rd }}$ & 91 & $0.585^{*}$ & $24.341 *$ & $1.010^{\mathrm{NS}}$ & \multirow{4}{*}{$\stackrel{\Xi}{\stackrel{0}{0}}$} & $3.885^{*}$ & $3.597^{\mathrm{NS}}$ & $3.769^{\mathrm{NS}}$ & \multirow{4}{*}{ 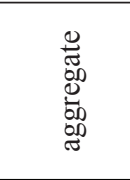 } \\
\hline & $14^{\mathrm{rd}}$ & 98 & $2.780^{*}$ & $35.959^{*}$ & $0.319^{\mathrm{NS}}$ & & $2.422^{*}$ & $3.266^{\mathrm{NS}}$ & $2.599 *$ & \\
\hline & $15^{\text {rd }}$ & 105 & $1.716^{\mathrm{NS}}$ & $25.666^{*}$ & $1.465^{\mathrm{NS}}$ & & $3.310^{*}$ & $2.606^{\mathrm{NS}}$ & $3.515^{*}$ & \\
\hline & $16^{\text {rd }}$ & 112 & $2.702^{\mathrm{NS}}$ & $27.946^{*}$ & $1.822^{\mathrm{NS}}$ & & $0.856^{*}$ & $2.291^{\mathrm{NS}}$ & $0.977 *$ & \\
\hline
\end{tabular}

* Significant at $5 \%$ probability. DAE $=$ Days after (plant) emergence.

ns - Not significant at $5 \%$ probability.

${ }^{\mathrm{i}}-$ Class insufficiently.

${ }^{\mathrm{NP}}$ - not present.

Source: Elaboration of the authors. 
Theoretical Distributions of Frequencies of Adults of $A$. grandis

The adjustment tests of the frequencies of numerical classes of adults of $A$. grandis observed in 14 samplings had sufficient numbers of classes to perform the adjustment test on the Bt cotton (Table 2).

The values for $A$. grandis adults on Bt crops indicate that the data did not fit the theoretical models of the Poisson distribution in 10 samplings, fit the negative binomial in 9 and the positive binomial in 6 (Table 2). Within the scope of ecological statistics, the best fit is represented by the frequency distribution that has the lowest calculated chi-square value $\left(\chi^{2}\right)$ (MELO et al., 2006). As most samples of adults resulted in a not significant value for $\chi^{2}$ by the negative binomial distribution method, they were consequently adjusted to this kind of dispersion. This means that the spatial arrangement found for adults of $A$. grandis is contagious with a tendency to uniformity (Table 2).

Fourteen samplings of adults of $A$. grandis taken from the non-Bt treatment had sufficient numbers of classes for the adjustment test to be applied. The $\chi^{2}$ values calculated for adults indicate that the field data obtained did not fit the theoretical models of the Poisson distribution in 11 samples, fit the negative binomial in 10 samples, and the positive binomial in 8 samples (Table 2).

\section{Theoretical distributions of frequencies for buds} with feeding punctures

The $\chi^{2}$ values obtained for buds with feeding punctures were within the 3 theoretical models of frequency distributions on Bt crops (Table 2). Count data obtained in the experimental area did not fit the theoretical model of the Poisson distribution in 13 samples, the negative binomial in 4 samples, and the binomial positive in 8 samples (Table 2).
The chi-square values for the buds with feeding punctures in non-Bt cotton were significant, i.e., values that indicate that the count data obtained in the field did not fit the theoretical Poisson distribution for 12 samples, negative binomial for 3 samples and the positive binominal for 7 samples (Table 2).

The random dispersion occurs because the pest starts by colonizing the edges and spreads in the field in search of reproductive structures. This explains the change in distribution behavior for random to aggregate, as observed in this study. The increase in the number of adults of the pest is due to overlapping generations during the season. The random arrangement did not explain the distribution of insects in the experimental areas. The uniform model fit the dispersion rates best. According Scarpellini e Busoli (1999), the horizontal distribution of the weevil is uniform from 80 days after plant emergence, participating more intensively in the shedding of the flower buds, starting the infestation on the edge of the field.

\section{Conclusions}

According to the rates of dispersion obtained for $A$. grandis adults there were similarities in distribution patterns on $\mathrm{Bt}$ and non $\mathrm{Bt}$ cotton, resulting in the following arrangements of probabilistic dispersion: the negative binomial distribution (aggregate) and positive binomial distribution (uniform), according to the number of DAE of the cultivars studied, and the increase of flower buds in the experimental areas.

Buds with feeding punctures were absent in the first 3 evaluations of Bt cotton plants and non-Bt. For the transgenic and conventional cotton, the spatial arrangement was as follows: Poisson (random), negative binomial distribution (aggregate) and positive binomial distribution (uniform). 


\section{Acknowledgments}

The 'Coordenação de Aperfeiçoamento de Pessoal de Nível Superior - CAPES', for financial support and field staff of the Faculdade de Ciências Agrárias - FCA/UFGD.

\section{References}

ALCANTRA, E.; MORAES, J. C.; ANTONIO, A.; ALVARENGA, R.; FRANÇOSO, J. Effect of silicon and acibenzolar-s-methyl on colored cotton plants infested or not with Aphis gossypii Glover (Hemiptera: Aphididae). Revista Brasileira de Entomologia, v. 55, n. 2, p. 279282, 2011.

BARBOSA, J. C. Métodos estatísticos aplicados à entomologia. Funep: Jaboticabal, 2003. 254 p.

BARBOSA, J. C.; PERECIN, D. Modelos probabilísticos para distribuições de lagartas de Spodoptera frugiperda (J. E. Smith, 1797), na cultura do milho. Cientifica, v. 10, n. 2, p.181-191, 1982.

BASTOS, C. S.; PEREIRA, M. J. B.; TAKIZAWA, E. K.; AQUINO, V. R. Bicudo do algodoeiro: identificação, biologia, amostragem e táticas de controle. Campina Grande: EMBRAPA Algodão, 2005. 31 p. (Circular técnica, 79).

BUSOLI, A. C. Práticas culturais, reguladores de crescimento, controle químico e feromônios no manejo integrado de pragas do algodão. In: DEGRANDE, P. E. (Ed.). Bicudo do algodoeiro: manejo integrado. Dourados: UFMS/EMBRAPA-UEPAE, 1991. p. 29-52.

BUSOLI, A. C.; PEREIRA, F. F.; LOPÉZ, V. A. G.; SOARES, J. J.; MELO, R. S.; ALMEIDA, C. A. Preferência alimentar do bicudo-do-algodoeiro por frutos de diferentes cultivares e idades. Pesquisa Agropecuária Brasileira, Brasília, v. 39, n. 2, p. 36-42, 2004.

CATTANEO, M. G.; YAFUSO, C.; SCHMIDT, C.; HUANG, C. Y.; RAHMAN, M.; OLSON, C.; ELLERSKIRK, C.; ORR, B. J.; MARSH, S. E.; ANTILLA, L.; DUTILLEUL, P.; CARRIÈRE, Y. Farm-scale evaluation of the impacts of transgenic cotton on biodiversity, pesticide use, and yield. Proceedings of the National Academy of Sciences of the United States of America, Washington, v. 103, n. 20, p.7571-7576, 2006.

CHOI, S. K.; KIM, K. S.; LEE, H.; ADAMCZYK, J. J.; GREENBERG, S. M.; WESTBROOK, J. K.; SAPPINGTON, T. W. Temporal changes in genetic variation of boll weevil (Coleoptera: Curculionidae) populations, and implications for population assignment in eradication zones. Annual Entomological Society of America, Lanham, v. 104, n. 4, p. 816-825, 2011.

DEGRANDE, P. E. Manejo integrado de pragas do algodoeiro. In: EMBRAPA. Centro de Pesquisas Agropecuária do Oeste (Dourados, MS). Algodão: informações técnicas. Dourados: EMBRAPA-CPAO; Campina Grande: EMBRAPA/CNPA,1998. p. 154-191. (Circular técnica, 7).

ELLIOT, J. M. Some methods for the statistical analysis of sample of benthic invertebrates. 2. ed. Freshwater Biological Association, Scientific Publication, 1979. 160 p.

FERNANDES, M. G.; BUSOLI, A. C.; BARBOSA, J. C. Amostragem seqüencial de Alabama argillacea (Hübner) (Lepidoptera: Noctuidae) em algodoeiro. Neotropical Entomology, Londrina, v. 32, n. 1, p. 117-122, 2003.

FONSECA, P. R. B. da; LIMA JUNIOR, I. S. de; SORIA, M. F.; KODAMA, C.; DEGRANDE, P. E. Inseticidas neonicotinoides no controle do bicudo-do-algodoeiro Anthonomus grandis (Boheman, 1843) (Coleoptera: Curculionidae) e a falha de controle do endosulfan. Arquivos do Instituto Biológico, São Paulo, v. 78, n. 4, p. 545-551, 2011.

LIU, X. D.; ZHAI, B. P.; ZHANG, X. X.; ZONG, J. M. Impact of transgenic cotton plants on a non-target pest, Aphis gossypii Glover. Ecological Entomology, Norwich, v. 30 , n. 1 , p. $307-315,2005$.

MELO, E. P.; FERNANDES, M. G.; DEGRANDE, P. E.; CESSA, R. M. A.; SALOMÃO, J. L.; NOGUEIRA, R. F. Distribuição espacial de plantas infestadas por Spodoptera frugiperda (J.E. Smith) (Lepidoptera: Noctuidae) na cultura do milho. Neotropical Entomology, v. 35, n. 5, p. 689-697, 2006.

MORISITA, M. Is index, a measure of dispersion of individuals. Researches on Population Ecology, v. 4, n. 1, p. 1-7, 1962.

NEVES, R. C. S.; J. B.; TORRES.; DA SILVA, M. N. B. Época apropriada para a poda apical do algodoeiro para o controle de pragas. Pesquisa Agropecuária Brasileira, Brasília, v. 45, n. 12, p. 1342-1350, 2010.

PIELOU, E. C. Mathematical ecology. $2^{\text {nd }}$ ed. New York: John Wiley \& Sons, 1977. 385 p.

POOLE, R. W. An introduction to quantitative ecology. New York: McGraw Hill, 1974. 525 p.

RABINOVICH, J. E. Introduccion a la ecologia de problaciones animales. México: Continental, 1980. 313 p. 
RODRIGUES, T. R. M. G.; FERNANDES, M. G.; SANTOS, H. R. dos. Distribuição espacial de Aphis gossypii (Glover) (Hemiptera: Aphididae) e Bemisia tabaci (Gennadius) biótipo B (Hemiptera: Aleyrodidae) em algodoeiro $\mathrm{Bt}$ e não-Bt. Revista Brasileira de Entomologia, Londrina, v. 54, n. 1, p. 136-143, 2010.

ROMEIS, J.; M. MEISSLE, M.; BIGLER, F. Transgenic crops expressing Bacillus thuringiensis toxins and biological control. Nature Biotechnology, Bethesda, v. 24, n. 1, p. 63-71, 2006.

SCARPELLINI, J. R.; BUSOLI, C. Infestação do bicudo do algodoeiro Anthonomus grandis Boheman (Coleoptera: Curculionidae) correlacionada a queda de botões florais em cultivares de algodoeiro. Arquivos do Instituto Biológico, São Paulo, v. 66, n. 1, p. 69-76, 1999.

SHARMA, H. C.; ORTIZ, R. Transgenics, pest management, and the environment. Current Science, Southampton, v. 79, n. 4, p. 421-437, 2000.
SILVA, F. P.; BEZERRA, A. P. L.; SILVA, A. F. Oviposição e alimentação do bicudo, Anthonomus grandis Boheman, em linhagens mutantes de algodoeiro herbáceo de cultura de soca. Revista Ciência Agronômica, Fortaleza, v. 39, n. 1, p. 85-89, 2008.

SOUTHWOOD, T. R. E. Ecological methods. 2. ed. New York, John Wiley \& Sons, 1978. 525 p.

THOMAZONI, D.; DEGRANDE, P. E.; SILVIE, P.; FACCENDA, O. Impact of Bollgard ${ }^{\circledR}$ genetically modified cotton on the biodiversity of arthropods under practical field conditions in Brazil. African Journal of Biotechnology, Nairobi, v. 9, n. 37, p. 6167-6176, 2010.

TOMQUELSKI, G. V. Ocorrência de pragas e custo de produção em algodoeiro geneticamente modificado (Bt) e convencional. 2009. Tese (Doutorado em Agronomia) Universidade Estadual Paulista Júlio de Mesquita Filho, Ilha Solteira.

YOUNG, L. J.; YOUNG, J. H. Statistical ecology: a population perspective. Boston: Kluwer Academic Publishers, 1998. $565 \mathrm{p}$. 